\title{
A severe dieback of box elder (Acer negundo) caused by Fusarium solani (Mart.) Sacc. in Turkey
}

\author{
F. Demirci ${ }^{\mathrm{A}, \mathrm{B}}$ and S. Maden ${ }^{\mathrm{A}}$ \\ ${ }^{A}$ University of Ankara, Faculty of Agriculture, Plant Protection Department, Dışkapı, Ankara 06110, Turkey. \\ ${ }^{\mathrm{B}}$ Corresponding author. Email: fdemirci@agri.ankara.edu.tr
}

Abstract. A severe dieback has recently been observed on box elder (Acer negundo) grown on roadsides and in gardens in Ankara, the capital of Turkey. Fusarium solani was isolated from diseased box elder branches and was identified as the causal agent of dieback on this host. Pathogenicity tests were carried out on young box elder shoots. Symptoms of the pathogen are illustrated.

Fusarium solani (Mart.) Sacc. has been isolated from an extremely wide range of both plant and animal tissue including ulcerated human tissue. It can cause root rot and stem cankers on many host plants. However, it is frequently found associated with damage or stress events caused by other biotic or abiotic agents (Booth 1971). Strains of F. solani have been associated with cankers of hardwood trees like teak (Tectona grandis) in Tanzania (Hocking 1968), mulberry (Broussonetia papyrifera) (Schreiber and Docinger 1967), yellow poplar (Liriodendron tulipifera L.) (Dochinger and Seliskar 1962), cottonwood (Populus deltoides) (Boyer 1961), musizi (Maesopsis emini) (Brown 1964), aspen (Populus tremuloides) (Maini and Dance 1965), tupelo (Nyssa sylvatica var. biflora) (Toole 1962), English walnut (Juglans regia L.) (Chen and Stewart 2000), spineless cactus (Opuntia ficus-indica) (Moura et al. 1998), tapiscia (Tapiscia sinensis) (Mei et al. 1999), red oak (Quercus rubra), (Toole 1966), citrus species (Citrus spp.) (Fawcett 1936) and black poplar (Populus nigra subs. betulifolia) (Barbee 1962). $F$. solani is considered to be the primary organism responsible for Fusarium canker of sugar maple (Acer saccharum) (Wood and Skelly 1964; Weidensaul and Wood 1973). Another fungus, the basidiomycete Inonotus rickii, was also reported to be the causal agent of canker and decay on Acer negundo L. in Italy (Annesi et al. 2003).

Severe dieback symptoms have been observed on many box elders (Acer negundo), a common tree in Ankara, Turkey. The diseased trees showed partial chlorosis and wilting on the infected branches. Infected branches had brown and red discoloration in their sapwood. The bark of the old infected branches peeled off and deep cracks were seen on them.

Box elder branches $5 \mathrm{~cm}$ in diameter showing dieback symptoms and red stain in the sapwood (Fig. 1) were removed from 2.5 to $3.0 \mathrm{~m}$ up the stems of different 20-25-year-old trees. A piece of wood was cut from the junction between diseased and healthy tissue showing the red stain and surface sterilised with $1 \% \mathrm{NaOCl}$ for 3 min and then plated onto PDA + streptomycin medium. After a week, similar fungal cultures were obtained from $90 \%$ of all isolations. Mycelial tips from these colonies were removed and inoculated on PDA. The Petri plates were incubated at $24^{\circ} \mathrm{C}$ for 10 days under fluorescent and black-light lamps with a $12 \mathrm{~h} \mathrm{~L}: 12 \mathrm{~h} \mathrm{D}$ photoperiod. Each culture was observed under a stereoscopic microscope and a small part of the mycelial mass containing spores was taken by a sterile needle and introduced into a drop of sterile water on a sterile microscope slide. The spore suspension was observed microscopically and a loop of the suspension was taken up and streaked onto plates containing water agar (1\%). These Petri plates were observed under a stereoscopic microscope after $24 \mathrm{~h}$ incubation. A mycelial tip which had been initiated from a single spore was taken up by a sterile needle tip and inoculated on PDA (Booth 1971). The fungus was identified as $F$. solani, based on the descriptions given by Booth (1971). The single spore cultures were preserved as spore suspensions in $10 \%$ glycerin at $-20^{\circ} \mathrm{C}$.

The fungus was grown on PDA for 10 days. One-yearold shoots of young box elder plants, which had been obtained from the ornamental plant nursery of the Faculty of Agriculture, University of Ankara, were surface disinfected with $70 \%$ ethanol and pieces of bark were split longitudinally with a sterile blade and inoculated with an agar piece $(3 \times 3 \mathrm{~mm})$ cut from the edge of the fungus culture. The control shoots were prepared in the same way but inoculated with sterile agar pieces. All the inoculated areas were covered with sterile wet cotton and completely encased 


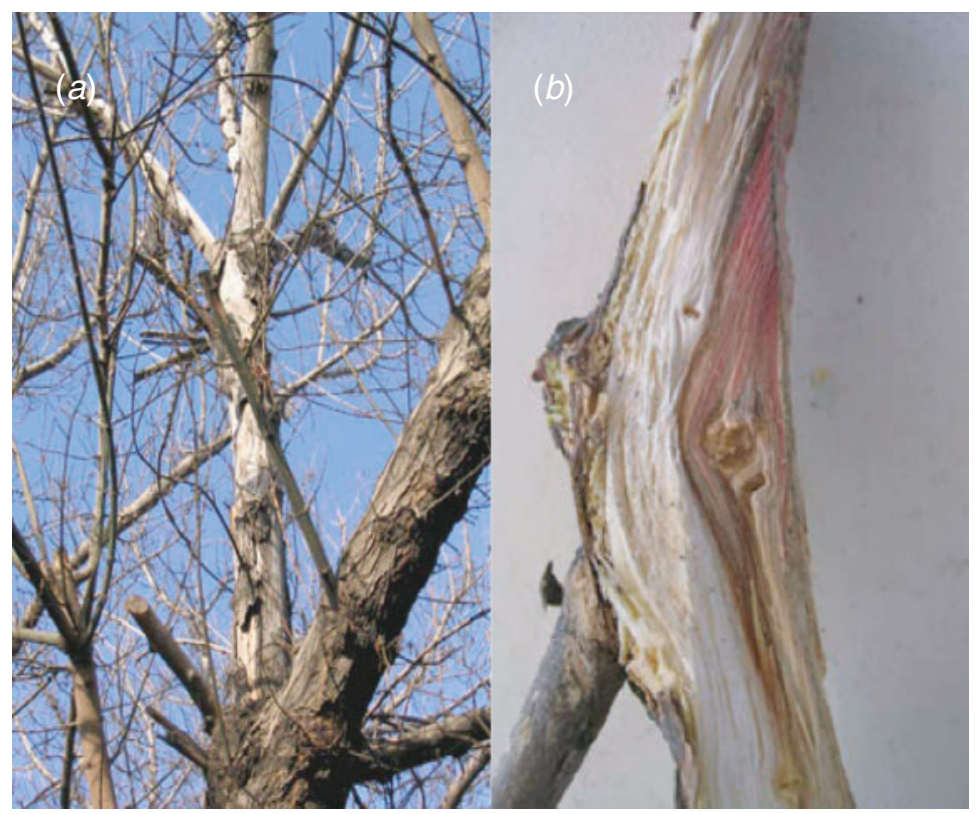

Fig. 1. A box elder tree showing (a) dieback symptoms and $(b)$ dark pigmentation in the core.

with aluminum foil to preserve humidity. The plants were incubated in a growth room at $25^{\circ} \mathrm{C}$ with a $14 \mathrm{~h} \mathrm{~L}: 10 \mathrm{~h} \mathrm{D}$ photoperiod. Lesion development was monitored daily. Disease symptoms were first observed on the third day after inoculation of the plants. No lesion development was seen on control plants (Fig. 2). The necrotic lesions girdled the shoots by the sixth day. The leaves above the lesions wilted severely because the fungus blocked water flow in the xylem.

Weidensaul and Wood (1973) stated that $F$. solani occurs in the healthy bark of sugar maple and that cankers may develop when wounds in the bark extend to the vicinity of the cambium. Such wounds may result from wind damage, a sudden drop in temperature or insect attack. Ankara has a terrestrial climate and the temperature may reach up to $40^{\circ} \mathrm{C}$ in summer and decrease to $-20^{\circ} \mathrm{C}$ in winter. Therefore, extreme low temperatures in winter could result in frost cracks which present suitable entry points for $F$. solani.

Fusarium reticulatum (F. negundi) was suggested as the cause of the red stain in box elder sapwood (Toole 1955), but the role of the fungus in producing the pigment has never been confirmed. Hepting (1971) investigated the red stain in the wood of living box elder trees and reported that it was caused by $F$. reticulatum var. negundinis. This pathogen is apparently specific to box elder, but is not known to cause any other disease symptoms on this host (Hepting 1971). Morse and Blanchette (2002) also studied the cause of red stain development in box elder wood. They inoculated box elder trees in the field with F. acuminatum, or Hypsizygus tessulatus

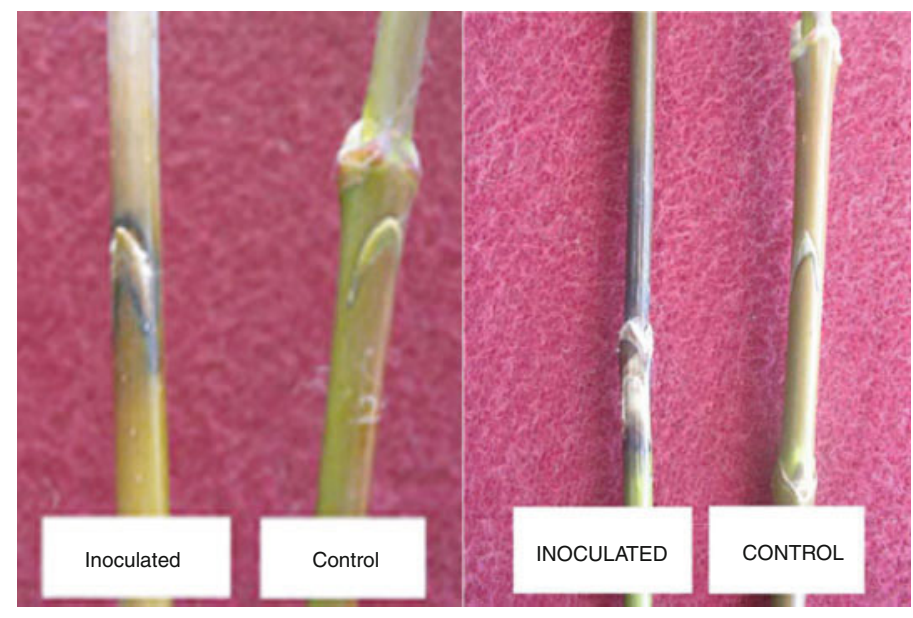

Fig. 2. F. solani-inoculated and non-inoculated Acer negundo shoots 6 days after inoculation. 
and used uninoculated plants as controls. Eight weeks after inoculation, F. solani was isolated from 67,17 , and $33 \%$ of the wounds inoculated with F. acuminatum, H. tessulatus, and the control, respectively. F. solani and $H$. tessulatus were unable to colonise red-stained box elder wood chips in laboratory studies. The authors concluded that the stain was produced by the tree as a non-specific host response. The results also indicate that $F$. solani is commonly found in the healthy bark of box elder. Wounding of the healthy bark resulted in $F$ solani infection.

In our study, $F$. solani was isolated from cankers of box elders showing red stain development in the wood and severe dieback symptoms. Pathogenicity was proved on young box elder shoots. It caused severe necrosis in the shoots. Red stain development was not observed. The lack of red stain development may be related to the young age of the box elder shoots.

\section{References}

Annesi T, Coppola R, Motta E (2003) Decay and canker caused by Inonotus rickii spreading on more urban tree species. Forest Pathology 33, 405-412. doi: 10.1046/j.1437-4781.2003.00340.x

Barbee JG (1962) Development of Fusarium canker of black poplars. (Abst.) Phytopathology 52, 724.

Booth C (1971) 'The genus Fusarium.' (Commonwealth Mycological Institute: Kew)

Boyer MG (1961) A Fusarium canker disease of Populus deltoides Marsh. Canadian Journal of Botany 39, 1195-1204.

Brown KW (1964) Observations on a stem canker of musizi (Maesopsis eminii Engl.). East African Agricultural Forest Journal 1, 54-58.

Chen W, Stewart WJ (2000) First report of stem canker of English walnut caused by Fusarium solani in South Africa. Plant Disease 84, 592.

Dochinger LS, Seliskar CE (1962) Fusarium canker found on yellow poplar. Journal of Forestry 60, 331-333.
Fawcett SH (1936) 'Citrus diseases and their control.' (Mc Graw-Hill Book Company Inc.: New York)

Hepting GH (1971) Diseases of forest and shade trees of the United States. US Department of Agriculture, Agriculture Handbook 386. Washington, DC.

Hocking D (1968) Stem canker and pink stain of Teak in Tanzania associated with Fusarium solani. Plant Disease Reporter 52, 628-629.

Maini JS, Dance BW (1965) Temperature relationships of blight attributed to Fusarium solani (Mart.) Sacc. on trembling aspen suckers. Canadian Department of Forest Rural Development Bi-Monthly Research Notes 21(2), 2.

Mei LY, Ming TC, Q1n GA, Na Z (1999) A study on the Pathogen for canker of Tapiscia sinensis. Journal of Northwest Forestry University 14, 53-58.

Morse AC, Blanchette RA (2002) Etiology of Red Stain in Box elder. Online. Plant Health Progress. doi: 10.1094/PHP-20020917-01-RS

Moura RM, Lira RV, Farias I, Menezes M, Santana AAD (1998) Fungal rots of the spineless cactus in state of Pernambuco. Fitopathologia Brasilleria 23, 180-182.

Schreiber LR, Docinger LS (1967) Fusarium canker on paper mulberry (Broussonetia papyrifera). Plant Disease Reporter 51, 531-532.

Toole RE (1955) Red stain of boxelder. Plant Disease Reporter 39, 66-67.

Toole RE (1962) Tupelo lesion caused by Fusarium solani. Plant Disease Reporter 46, 732-733.

Toole RE (1966) Stem canker of red oaks caused by Fusarium solani. Plant Disease Reporter 50, 160-161.

Weidensaul TC, Wood FA (1973) Sources of Fusarium in northern hardwood forests. Phytopathology 63, 367-371.

Wood FA, Skelly JM (1964) The etiology of an annual canker on maple. Phytopathology 54, 269-273.

Accepted 5 September 2006 